\title{
EFFECTS OF LED SUPPLEMENTARY LIGHTING AND NPK FERTILIZATION ON FRUIT QUALITY OF MELON (CUCUMIS MELO L.) GROWN IN PLASTIC HOUSE
}

\author{
Somsak KRAMCHOTE*, Somchai GLAHAN \\ Department of Plant Production Technology, Faculty of Agricultural Technology \\ King Mongkut's Institute of Technology Ladkrabang, \\ Bangkok, Chalongkrung Road, Ladkrabang, Bangkok 10520, Thailand
}

Received: August 2019; Accepted: May 2020

\begin{abstract}
Melon (Cucumis melo L.) is a high-value fruit in Thailand, usually grown in plastic houses where light could become a major limiting growth factor. This study used melon cultivar ' \#120' (orange flesh) grown in a plastic house under natural daylight (NDL, control) and with supplementary lighting using light emitting diodes (LEDs) of a combination of red $630 \mathrm{~nm}$, red $660 \mathrm{~nm}$, blue $450 \mathrm{~nm}$, blue $460 \mathrm{~nm}$, white $14000 \mathrm{~K}$, UV $410 \mathrm{~nm}$ and IR $730 \mathrm{~nm}$ (LED1) or a combination of red $630 \mathrm{~nm}$, red $660 \mathrm{~nm}$, blue $450 \mathrm{~nm}$ and blue $460 \mathrm{~nm}$ (LED2) applied for $12 \mathrm{~h}$ from 6:00 pm to 6:00 am. These lighting treatments were combined with NPK fertilization using complete fertilizer 15-15-15 $\left(\mathrm{N}-\mathrm{P}_{2} \mathrm{O}_{5}-\mathrm{K}_{2} \mathrm{O}\right)$ at $5 \mathrm{~g}, 7 \mathrm{~g}$ (recommended rate) or $9 \mathrm{~g}$ per plant. Results showed that LED2 combined with 9 g 15-15-15 was the most effective in increasing plant height, chlorophyll content (SPAD index), fruit size and mass, and peel and flesh thickness. The fruit also developed the desired lighter color (higher $\mathrm{L}^{*}$ and lower $\mathrm{a}^{*}$ coordinates) and were the firmest and sweetest (highest soluble solids content and lowest titratable acidity) among all treatments.
\end{abstract}

Key words: light-emitting diode; nitrogen, phosphorus and potassium fertilizer; plant growth and development; fruit physicochemical properties

\section{INTRODUCTION}

Melon (Cucumis melo L.), also known as muskmelon, cantaloupe, sweet melon, round melon or winter melon, is a member of the Cucurbitaceae family, which includes cucumbers, pumpkins, squashes, gourds, watermelon and loofah (IPGRI 2003). It is a variable, trailing, softly hairy annual plant and is mainly grown for its fruit, which is rich in carbohydrates, minerals, dietary fiber and bioactive compounds, such as phenolics, flavonoids and vitamins. The fruit vary in size and shape but most cultivars have round fruit. In Thailand, melon is grown in plastic houses, also called melon houses, because openfield cultivation often failed due to low yields, poor fruit quality, and insect pest problems, which requires excessive pesticide application that compromises food safety and market acceptability, particularly export. Melon production has provided former rice farmers more than 20-fold increase in yearly income from much smaller farm areas than rice farming (Srimalee 2016). Crop cultivation under plastic houses is increasingly employed to obtain high yields and better produce quality to help in minimizing the impact of environmental constraints including climate change, depleting arable land area and growing population that is becoming more quality and health conscious.

Under protected cultivation, like in melon houses, light could become a major limiting factor as the structural enclosure affects light quantity and quality. Light is required for photosynthesis and initiates signaling cascade of specific photoreceptors, such as phytochromes (absorbs red/far-red-light) and cryptochromes (absorbs blue/UV-A light), which alter the expression of a large number of genes regulating plant morphological and developmental processes (Olle \& Viršilè 2013; Hasan et al. 2017). Fluorescent and incandescent lamps or high-pressure sodium (HPS) 
lamps have been traditionally used for plant supplementary lighting but they have short half-life, high heat production, and high electrical power consumption.

Light emitting diodes (LEDs) are emerging as promising tool for protected crop cultivation (Bourget 2008; Mitchell et al. 2012; Hasan et al. 2017). LED is a unique type of semiconductor diode that emits light wavelengths from UV-C $(250 \mathrm{~nm})$ to infrared $(1000 \mathrm{~nm})$ and has the capability of true spectral control allowing wavelengths to be matched to plant photoreceptors to provide more optimal productivity and product quality. LEDs do not generally burn out like traditional lamps, with lifetime (time to dim to $70 \%$ of its original intensity) of 50,000 hours or longer. LEDs consume less electricity and generate less heat enabling their use close to the plants even at high light intensities. They also have no fragile glass envelope to break, no high touch temperature and no hazardous materials, such as mercury.

Red light $(620-660 \mathrm{~nm})$ is usually the basal component in lighting spectra but different wavelengths of red light could have uneven effects on plants. Earlier studies used only red $660 \mathrm{~nm}$ LEDs as this wavelength is close to the chlorophyll and Pr phytochrome absorption maxima but showed the need to enrich red LED lighting with blue (400$500 \mathrm{~nm}$ ) visible region light (Yorio et al. 2001). Blue light is required for normal chloroplast structure and leaf anatomy to prevent overt dysfunctional photosynthesis; it activates cryptochrome system; and matches chlorophyll and carotenoid absorption spectra. Blue LEDs (440-476 nm) alone or in combination with red LEDs caused higher chlorophyll ratio, increased biomass accumulation, and stimulated antioxidant system (polyphenol, vitamin C, carotenoid and anthocyanin contents) in plants ( $\mathrm{Li}$ \& Kubota 2009; Yorio et al. 2001; Li et al. 2012). Blue LEDs (450-470 nm) combined with red LEDs also increased the photosynthetic capacity and plant biomass in tomato, cucumber and pepper transplants (Hernández \& Kubota 2012; Samuolienè et al. 2012a). Furthermore, single or mixed blue and red LEDs improved the quality and yield of vegetables and fruit when compared with white fluorescent or solar light (Hao et al. 2012; Dong et al. 2014; Choi et al. 2015; Li et al. 2016; Xie et al. 2016; Nadalini et al. 2017). As blue and red light control the rates of photosynthesis through the opening and/or closing of stomata, their effect on plant biomass or yield was anticipated (Sabzalian et al. 2014). In certain cases, small flux of UV-A LED may be useful for anthocyanin production (Li \& Kubota 2009), while far red light, which acts on phytochrome photoconversion may be necessary for normal photomorphogenetic processes but is too far beyond the photosynthetically active region range. In melon 'Yumeiren', LED lighting promoted seedling growth and improved the fruit yield, and sugar and volatile compounds contents, with the $6: 1$ red : blue LED as the most effective. In this study, seedlings were light treated for 2 weeks with red, blue, and $3: 1,6: 1$ and $8: 1$ red : blue LED starting at the three-leaf stage, while the developing fruit were treated at 10 days after anthesis for 5, 10, 15 , and 20 days with red, blue, and $6: 1$ red : blue LED (Cui et al. 2017).

Aside from light, proper mineral nutrition of plants is important to improve yield and quality. Nutrient requirement of plastic house grown plants could differ with that grown under open-field conditions. Several studies reported the importance of NPK fertilization of melon plants, which increases plant growth (El-Desuki et al. 2000). The most effective was application $200 \mathrm{~N}+210 \mathrm{P}_{2} \mathrm{O}_{5}+230$ $\mathrm{K}_{2} \mathrm{O}$ kg per ha, which most increased fruit yield and quality (fruit size, weight, and flesh thickness). Under plastic house conditions, fertilization of melon

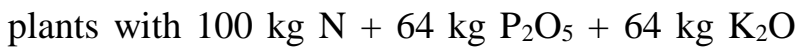
resulted in the highest increase in plant height, number of leaves and shoots, fresh and dry weights, fruit yield (number of fruits, fruit mass and fruit size, length and diameter) and fruit quality (protein and vitamin $\mathrm{C}$ contents) but total sugar, TSS and moisture contents were not affected (Shafeek et al. 2015). These results were attributed to increased NPK availability and uptake for the various metabolic processes in the plant (Mengel \& Kirkby 1978). Similar results were obtained in previous studies (Ferrante et al. 2008; Wang \& Sun 2008).

Under plastic house conditions for melons where natural daylight is involved, the combined effects of natural lighting and LED supplemental lighting should be examined as plant responses are difficult to predict due to the complex interaction of different growth factors (Samuoliene et al. 2012b). NPK fertilization could contribute to the complexity of plant reactions to LED lighting. Thus, this study was conducted to determine the effects of two types of LED lighting in combination with NPK fertilization of growth and fruit quality of melon. 


\section{MATERIALS AND METHODS}

\section{Plant material and growth conditions}

Melon plants cultivar '\#120' (orange flesh) were grown in 2017 in a plastic house located at the experimental farm of the Department of Plant Production Technology, Faculty of Agricultural Technology, King Mongkut's Institute of Technology Ladkrabang (KMITL), Thailand. The plastic house was covered with $0.15 \mathrm{~mm}$-thick polyethylene plastic film. Seeds were sown in polystyrene transplant flats filled with peat moss. When seedlings had two to three true leaves (about two weeks from sowing), they were transplanted individually into $20 \times 33 \mathrm{~cm}$ black polyethylene bags filled with $3: 1$ garden soil: cow manure mixture. Before transplanting, the soil mix in bags were saturated with water and allowed to drain through small horizontal slits about $4 \mathrm{~cm}$ from the ground. Nine bags were used for each treatment, each bag representing one replicate and all were taken for measurement of responses throughout the experiment. The bags were spaced at $0.4 \times 0.6 \mathrm{~m}$ as usually practiced. Other cultural management practices, such as trellising, irrigation, pesticide application and weed control, followed commercial recommendations for plastic house-grown melons.

\section{Experimental design and treatments}

A $3 \times 3$ factorial experiment in completely randomized design (CRD) with nine replications was used, with LED supplementary lighting as factor A and fertilizer application as factor B. Lighting treatments were: natural day light (NDL) as control; NDL plus LED1 (red $630 \mathrm{~nm}$, red $660 \mathrm{~nm}$, blue $450 \mathrm{~nm}$, blue $460 \mathrm{~nm}$, white $14000 \mathrm{~K}$, UV $410 \mathrm{~nm}$ and IR $730 \mathrm{~nm}$ ) and NDL plus LED2 (red $630 \mathrm{~nm}$, red $660 \mathrm{~nm}$, blue $450 \mathrm{~nm}$ and blue $460 \mathrm{~nm}$ ). For LED1, APL-G300W-03 lamps (Forest Grower, China) were used, while for LED2, APL-G-F4-75X4W lamps (Forest Grower, China). LED supplementary lighting was applied every day for $12 \mathrm{~h}$ from 6:00 pm to 6:00 am, starting one week after transplanting and ending one week before harvest. Fertilizer application used complete fertilizer 15-15-15 $\left(\mathrm{N}-\mathrm{P}_{2} \mathrm{O}_{5}-\mathrm{K}_{2} \mathrm{O}\right)$ at 5, 7, and $9 \mathrm{~g}$ per plant. The fertilizer was applied weekly starting after transplanting and until a week before harvesting. Commercial practice used $7 \mathrm{~g}$ 15-15-15 per plant applied weekly similar to the present study.

\section{Fruit setting and harvesting}

The plants flowered after 20-27 days from transplanting. Hand pollination was done and one fruit was maintained per plant. At commercial maturity (about 50 days from fruit setting), the fruits were harvested for quality evaluation.

\section{Measurement of responses}

Plant growth was monitored weekly in terms of height increment and leaf chlorophyll content. Plant height was determined starting on the second week after transplanting up to two weeks before harvest. Chlorophyll content was non-destructively measured using SPAD-502 chlorophyll meter (Minolta Camera Co., Japan) starting at fruit set (about four weeks after transplanting) up to two weeks before harvest. The results were the average of readings taken from three index leaves (lower and upper leaf surface reading) near the developing fruit, which were used throughout the measurement period.

Fruit quality was evaluated in terms of physical and chemical attributes. Fruit size was measured by taking the diameter at the middle or equatorial part of the fruit using a Vernier caliper. Fruit mass was taken using a digital weighing scale (Adventurer, OHAUS Corp., USA). Fruit volume was determined by displacement method by placing the fruit in a container filled to the rim with water and measuring the spilled water with a graduated cylinder. Fruit peel and flesh thickness were measured using a Vernier caliper. Fruit firmness was determined using a firmness tester (Atago TR-53025, Italy). Fruit peel color was measured using a Hunterlab Colorimeter (ColorFlex, Hunter Lab, USA) taking the average of five readings of $L^{*}, a^{*}$ and $b^{*}$ values from the top, middle and bottom parts of each fruit. As chemical attributes, total soluble solids (TSS) content, titratable acidity (TA) and $\mathrm{pH}$ were determined. TSS was measured using a refractometer (Model PAL-1, Tokyo, Japan). For TA analysis, $10 \mathrm{~g}$ of pulp tissue was homogenized with $40 \mathrm{ml}$ of distilled water. The homogenate was filtered through cotton wool. To the $5 \mathrm{ml}$ of filtrate one to two drops of $0.1 \%$ phenolphthalein indicator was added and titrated using $0.1 \mathrm{~N} \mathrm{NaOH}$ to an endpoint of faint pink color ( $\mathrm{pH} 8.1$ ). The results were expressed as percentage malic acid per $100 \mathrm{~g}$ fresh weight. $\mathrm{pH}$ was measured using a digital $\mathrm{pH}$ meter (Model HI2213, Hanna Instruments, USA). 


\section{Statistical analysis}

The results were analyzed by performing analysis of variance (ANOVA) and treatment means comparison by the Tukey's honest significance test (HSD; $\mathrm{p}<0.05$ ) using Statistix 8 software (Analytical Software, USA).

\section{RESULTS AND DISCUSSION}

\section{Plant growth characteristics}

The plants grew more rapidly with LED supplementary lighting as compared with the natural day light control (Table 1). LED-treated plants were significantly higher than the control throughout the whole experiment. LED2 was more effective than LED1 in stimulation of plant growth. Plant height also increased with increasing the amount of NPK fertilization. Differences between the three NPK treatments were significant at each term of observation. Interaction effect was significant throughout the observation period as some treatments did not follow the main effect of LED lighting and NPK application. For example, at 14 days from transplanting, plants fertilized with $5 \mathrm{~g}$ and $7 \mathrm{~g}$ NPK had statistically comparable height under LED1 or LED2 conditions. At 63rd day from transplanting, heights of plants exposed to LED1 or LED2 and fertilized with $7 \mathrm{~g}$ were comparable to that of plants fertilized with $5 \mathrm{~g}$ or $9 \mathrm{~g}$ but between $5 \mathrm{~g}$ and $9 \mathrm{~g}$, differences were significant.

Chlorophyll content generally decreased with the fruit development and maturation (Table 2). LED lighting maintained higher chlorophyll content except at 49 and 56 weeks from transplanting, in which chlorophyll contents from all treatments were statistically comparable. LED2 was most effective in maintaining high chlorophyll content. LED1 resulted in significantly higher chlorophyll content than the control only at 63rd week. Plants fertilized with $9 \mathrm{~g}$ had significantly higher chlorophyll content than those fertilized with $5 \mathrm{~g}$ through the experiment. Significant interaction effect was obtained except at 49 and 56 weeks from transplanting. At 28th week from transplanting, only LED2 lighting plus $9 \mathrm{~g}$ of fertilizer resulted in significantly higher chlorophyll as compared with the control plus
$5 \mathrm{~g}$ fertilizer. At 35 th and 42 nd day from transplanting, both $7 \mathrm{~g}$ and $9 \mathrm{~g}$ of fertilizer under LED2 lighting resulted in significantly higher chlorophyll content than the control with $5 \mathrm{~g}$. At $63 \mathrm{rd}$ week, the three NPK treatments under LED2 lights had comparable chlorophyll contents but significantly higher than that of the control with $5 \mathrm{~g}$ fertilizer.

The results are in agreement with previous findings, particularly those reporting on the promotive effect of red-blue LED (LED2) on plant biomass and chlorophyll development (Li \& Kubota 2009; Yorio et al. 2011; Li et al. 2012). In melon, Cui et al. (2017) found that exposure to red-blue LEDs resulted in increased plant height and maximum net photosynthetic rate. In other crops - tomato, cucumber, pepper and strawberry, blue $(450-470 \mathrm{~nm})$ plus red $(620-660 \mathrm{~nm})$ LEDs increased plant biomass and photosynthetic capacity of the plants (Hernández \& Kubota 2012; Samuolienè et al. 2012a; Piovene et al. 2015). It was reported that plants are sensitive to radiation wavelengths from UV (280$400 \mathrm{~nm})$ to far-red $(700-800 \mathrm{~nm})$, with blue and red wavelengths as the most effective regions influencing overall plant growth and yield (Folta \& Carvalho 2015). These radiations are primarily absorbed by the chlorophyll pigments, which initiate the photosynthetic process (Ouzounis et al. 2015; Huché-Thélier et al. 2016). However, the entire spectrum of light is not beneficial for plants; UV and infrared radiations could adversely affect growth processes (Morrow 2008; Mitchell et al. 2012). This may account for the lower effectiveness of LED1 (red-blue with white, UV and IR components) than LED2 in promoting growth and chlorophyll development. On the other hand, NPK fertilization increased plant height and generally favored chlorophyll synthesis. Increasing the NPK level from the recommended rate of $7 \mathrm{~g}$ NPK 15-15-15 per plant to $9 \mathrm{~g}$ also increased plant height and chlorophyll content. In an earlier study on melon, application of the recommended fertilizer rate in combination with organic fertilizer was the most effective in increasing plant growth parameters than using $50 \%$ or $75 \%$ lower than the recommended dose (Shafeek et al. 2015). Inorganic NPK fertilizers are more easily available to plants then organic ones. 
Table 1. Plant height $(\mathrm{cm})$ of melon in response to LED supplementary lighting and complete fertilizer (NPK 15-15-15) application

\begin{tabular}{|c|c|c|c|c|c|c|c|c|}
\hline \multirow{2}{*}{ Treatments } & \multicolumn{8}{|c|}{ Days after transplanting } \\
\hline & 14 & 21 & 28 & 35 & 42 & 49 & 56 & 63 \\
\hline \multicolumn{9}{|c|}{ Main factor-LED } \\
\hline No LED & $43.8 \pm 3.3 \mathrm{c}$ & $122.6 \pm 16.2 \mathrm{c}$ & $151.3 \pm 9.8 \mathrm{c}$ & $153.8 \pm 25.3 \mathrm{c}$ & $155.0 \pm 8.6 \mathrm{c}$ & $157.8 \pm 26.3 \mathrm{c}$ & $158.8 \pm 15.6 \mathrm{c}$ & $170.8 \pm 5.3 \mathrm{c}$ \\
\hline LED1 & $51.3 \pm 2.1 b$ & $131.5 \pm 12.3 b$ & $173.0 \pm 7.7 b$ & $174.9 \pm 32.2 b$ & $176.2 \pm 11.3 b$ & $177.9 \pm 17.3 b$ & $178.9 \pm 11.5 b$ & $178.7 \pm 4.3 b$ \\
\hline LED2 & $64.1 \pm 1.6 \mathrm{a}$ & $145.1 \pm 15.5 \mathrm{a}$ & $187.3 \pm 5.9 \mathrm{a}$ & $190.2 \pm 28.4 \mathrm{a}$ & $191.4 \pm 12.3 \mathrm{a}$ & $193.3 \pm 17.9 \mathrm{a}$ & $194.4 \pm 11.5 \mathrm{a}$ & a $185.9 \pm 14.3 \mathrm{a}$ \\
\hline F-value & 18.4 & 26.1 & 12.3 & 34.2 & 9.8 & 25.2 & 38.2 & 56.2 \\
\hline Significance & $* *$ & $*$ & $*$ & $*$ & $*$ & * & $*$ & $*$ \\
\hline \multicolumn{9}{|c|}{ Sub-factor-Complete fertilizer $(\mathrm{CF})$} \\
\hline $5 \mathrm{~g} \mathrm{CF}$ per plant & $50.1 \pm 1.6 \mathrm{c}$ & $129.1 \pm 14.6 \mathrm{c}$ & $163.0 \pm 19.5 \mathrm{c}$ & $165.0 \pm 12.3 \mathrm{c}$ & $166.1 \pm 11.3 \mathrm{c}$ & $168.6 \pm 12.4 \mathrm{c}$ & $169.5 \pm 8.3 \mathrm{c}$ & $160.4 \pm 8.5 \mathrm{c}$ \\
\hline $7 \mathrm{~g} \mathrm{CF}$ per plant & $52.5 \pm 2.5 b$ & $133.4 \pm 12.3 b$ & $170.9 \pm 15.4 b$ & $173.0 \pm 12.1 b$ & $174.6 \pm 16.2 b$ & $176.6 \pm 18.6 b$ & $177.6 \pm 11.4 b$ & $179.9 \pm 13.3 b$ \\
\hline $9 \mathrm{~g} \mathrm{CF}$ per plant & $56.6 \pm 3.3 \mathrm{a}$ & $136.7 \pm 14.9 \mathrm{a}$ & $177.7 \pm 17.6 \mathrm{a}$ & $180.8 \pm 15.2 \mathrm{a}$ & $181.9 \pm 11.3 \mathrm{a}$ & $183.9 \pm 17.4 \mathrm{a}$ & $185.0 \pm 13.7 \mathrm{a}$ & $185.9 \pm 17.2 \mathrm{a}$ \\
\hline F-value & 23.5 & 65.0 & 37.4 & 27.9 & 13.2 & 34.9 & 31.2 & 21.7 \\
\hline Significance & $*$ & $*$ & $*$ & $*$ & $*$ & $*$ & $*$ & $*$ \\
\hline \multicolumn{9}{|c|}{ Interaction effect $(\mathrm{LED} \times \mathrm{CF})$} \\
\hline $\begin{array}{l}\text { No LED }+5 \text { g CF } \\
\text { per plant }\end{array}$ & $41.0 \pm 2.5 \mathrm{~g}$ & $119.0 \pm 8.5 \mathrm{~g}$ & $137.9 \pm 14.3 \mathrm{~h}$ & $140.0 \pm 12.1 \mathrm{f}$ & $141.5 \pm 21.3 \mathrm{~g}$ & $144.7 \pm 8.7 \mathrm{~g}$ & $145.5 \pm 9.3 \mathrm{~h}$ & $147.6 \pm 9.4 \mathrm{~h}$ \\
\hline $\begin{array}{l}\text { No LED }+7 \mathrm{~g} \mathrm{CF} \\
\text { per plant }\end{array}$ & $44.0 \pm 6.3 f$ & $123.3 \pm 9.2 \mathrm{f}$ & $153.4 \pm 17.5 \mathrm{~g}$ & $155.2 \pm 11.2 \mathrm{e}$ & $156.3 \pm 15.2 \mathrm{f}$ & $159.2 \pm 11.3 \mathrm{f}$ & $160.1 \pm 4.7 \mathrm{~g}$ & $161.6 \pm 7.7 \mathrm{~g}$ \\
\hline $\begin{array}{l}\text { No LED }+9 \mathrm{~g} \mathrm{CF} \\
\text { per plant }\end{array}$ & $46.3 \pm 5.3 \mathrm{ef}$ & f $125.4 \pm 7.4 \mathrm{ef}$ & $162.8 \pm 6.3 \mathrm{f}$ & $166.2 \pm 12.2 \mathrm{~d}$ & $167.1 \pm 10.7 \mathrm{e}$ & $169.7 \pm 24.3 \mathrm{e}$ & $170.7 \pm 15.3 \mathrm{f}$ & $172.1 \pm 9.9 \mathrm{f}$ \\
\hline $\begin{array}{l}\mathrm{LED} 1+5 \mathrm{~g} \mathrm{CF} \\
\text { per plant }\end{array}$ & $48.3 \pm 4.2 \mathrm{~d}$ & e $127.4 \pm 4.3 \mathrm{de}$ & $167.4 \pm 14.3 \mathrm{f}$ & $169.0 \pm 12.3 \mathrm{~d}$ & $170.0 \pm 4.2 \mathrm{e}$ & $172.1 \pm 8.2 \mathrm{de}$ & $172.8 \pm 14.3 \mathrm{ef}$ & $174.0 \pm 7.9 \mathrm{ef}$ \\
\hline $\begin{array}{l}\text { LED } 1+7 \text { g CF } \\
\text { per plant }\end{array}$ & $50.2 \pm 5.2 \mathrm{~d}$ & $131.2 \pm 13.3 \mathrm{~d}$ & $172.4 \pm 8.3 \mathrm{~d}$ & $173.7 \pm 14.5 \mathrm{c}$ & $175.6 \pm 8.3 \mathrm{~d}$ & $177.3 \pm 13.3 \mathrm{~d}$ & $178.4 \pm 11.3 \mathrm{de}$ & $179.4 \pm 11.6 \mathrm{de}$ \\
\hline $\begin{array}{l}\text { LED } 1+9 \mathrm{~g} \mathrm{CF} \\
\text { per plant }\end{array}$ & $55.5 \pm 4.3 \mathrm{c}$ & $135.9 \pm 11.4 \mathrm{c}$ & $179.1 \pm 16.3 \mathrm{c}$ & $181.9 \pm 8.2 b$ & $183.0 \pm 9.3 \mathrm{c}$ & $184.5 \pm 12.1 \mathrm{c}$ & $185.4 \pm 14.2 \mathrm{~cd}$ & $186.3 \pm 18.2 \mathrm{~cd}$ \\
\hline $\begin{array}{l}\mathrm{LED} 2+5 \mathrm{~g} \mathrm{CF} \\
\text { per plant }\end{array}$ & $60.9 \pm 2.3 b$ & $141.0 \pm 5.8 \mathrm{~b}$ & $183.7 \pm 19.3 b$ & $185.8 \pm 7.3 \mathrm{~b}$ & $186.9 \pm 7.3 \mathrm{bc}$ & $189.0 \pm 7.2 \mathrm{bc}$ & $190.1 \pm 17.6 b c$ & $190.7 \pm 14.2 b c$ \\
\hline $\begin{array}{l}\mathrm{LED} 2+7 \mathrm{~g} \mathrm{CF} \\
\text { per plant }\end{array}$ & $63.3 \pm 3.3 b$ & $145.6 \pm 11.3 \mathrm{a}$ & $186.9 \pm 15.3 \mathrm{ab}$ & $190.2 \pm 5.9 \mathrm{a}$ & $192.0 \pm 8.4 \mathrm{ab}$ & $193.4 \pm 16.4 \mathrm{ab}$ & $194.4 \pm 12.6 \mathrm{ab}$ & $195.1 \pm 13.3 \mathrm{ab}$ \\
\hline $\begin{array}{l}\mathrm{LED} 2+9 \mathrm{~g} \mathrm{CF} \\
\text { per plant }\end{array}$ & $68.0 \pm 2.7 \mathrm{a}$ & $148.8 \pm 11.1 \mathrm{a}$ & $191.3 \pm 11.3 \mathrm{a}$ & $194.4 \pm 6.9 \mathrm{a}$ & $195.4 \pm 9.4 \mathrm{a}$ & $197.6 \pm 14.7 \mathrm{a}$ & $198.8 \pm 11.4 \mathrm{a}$ & $199.2 \pm 17.3 \mathrm{a}$ \\
\hline F-value & 42.0 & 57.2 & 19.5 & 65.3 & 43.2 & 48.3 & 27.5 & 23.5 \\
\hline Significance & $*$ & $*$ & $*$ & $*$ & $*$ & $*$ & $*$ & $*$ \\
\hline $\mathrm{CV}(\%)$ & 1.8 & 1.0 & 0.9 & 0.4 & 1.0 & 1.2 & 1.4 & 1.4 \\
\hline
\end{tabular}

Note: LED1-red $630 \mathrm{~nm}$, red $660 \mathrm{~nm}$, blue $460 \mathrm{~nm}$, blue $450 \mathrm{~nm}$, white $14000 \mathrm{~K}$, UV $410 \mathrm{~nm}$ and IR $730 \mathrm{~nm}$; LED2-red 630 nm, red $660 \mathrm{~nm}$, blue $450 \mathrm{~nm}$ and blue $460 \mathrm{~nm}$. No letter assignment of means per factor indicates no significant differences. Means in a column per factor with the same letter are not significantly different based on Tukey's HSD test $(\mathrm{p}=0.05)$ 
Table 2. Leaf chlorophyll content (SPAD unit) in melon leaves in response to LED supplementary lighting and complete fertilizer (NPK 15-15-15) application

\begin{tabular}{|c|c|c|c|c|c|c|}
\hline \multirow{2}{*}{ Treatments } & \multicolumn{6}{|c|}{ Days after transplanting } \\
\hline & 28 & 35 & 42 & 49 & 56 & 63 \\
\hline \multicolumn{7}{|c|}{ Main factor-LED } \\
\hline No LED & $51.7 \pm 4.2 \mathrm{~b}$ & $50.2 \pm 3.7 \mathrm{~b}$ & $50.0 \pm 3.6 \mathrm{~b}$ & $45.1 \pm 4.3 b$ & $41.9 \pm 2.9 \mathrm{~b}$ & $29.3 \pm 2.9 c$ \\
\hline LED1 & $54.0 \pm 5.6 \mathrm{ab}$ & $52.6 \pm 3.5 \mathrm{ab}$ & $52.0 \pm 4.2 b$ & $47.2 \pm 4.0 \mathrm{ab}$ & $43.7 \pm 3.2 \mathrm{a}$ & $31.5 \pm 3.7 \mathrm{~b}$ \\
\hline LED2 & $58.3 \pm 4.7 \mathrm{a}$ & $57.6 \pm 3.5 \mathrm{a}$ & $56.2 \pm 4.0 \mathrm{a}$ & $48.3 \pm 6.2 \mathrm{a}$ & $43.9 \pm 3.0 \mathrm{a}$ & $34.6 \pm 5.0 \mathrm{a}$ \\
\hline F-value & 12.8 & 15.8 & 9.6 & 32.2 & 27.4 & 21.2 \\
\hline Significance & $*$ & $*$ & $*$ & $*$ & $*$ & $*$ \\
\hline \multicolumn{7}{|c|}{ Sub-factor-Complete fertilizer (CF) } \\
\hline $5 \mathrm{~g} \mathrm{CF}$ per plant & $53.9 \pm 5.3 b$ & $52.4 \pm 5.6 b$ & $52.2 \pm 2.4 \mathrm{~b}$ & $45.8 \pm 3.3 b$ & $41.7 \pm 2.4 b$ & $30.7 \pm 2.6 b$ \\
\hline $7 \mathrm{~g} \mathrm{CF}$ per plant & $54.4 \pm 4.6 \mathrm{ab}$ & $53.3 \pm 4.3 \mathrm{ab}$ & $53.0 \pm 2.7 \mathrm{a}$ & $45.9 \pm 2.7 b$ & $42.4 \pm 2.7 \mathrm{ab}$ & $31.3 \pm 2.6 \mathrm{ab}$ \\
\hline $9 \mathrm{~g} \mathrm{CF}$ per plant & $55.1 \pm 3.7 \mathrm{a}$ & $55.0 \pm 2.3 \mathrm{a}$ & $53.5 \pm 2.3 \mathrm{a}$ & $49.0 \pm 2.9 \mathrm{a}$ & $45.3 \pm 2.4 \mathrm{a}$ & $33.3 \pm 1.3 \mathrm{a}$ \\
\hline F-value & 17.7 & 21.4 & 43.5 & 61.3 & 35.0 & 54.4 \\
\hline Significance & $*$ & $*$ & * & $*$ & $*$ & $*$ \\
\hline \multicolumn{7}{|c|}{ Interaction effect $(\mathrm{LED} \times \mathrm{CF})$} \\
\hline No LED + 5 g CF per plant & $49.6 \pm 4.3 b$ & $47.9 \pm 3.6 b$ & $46.0 \pm 6.3 b$ & $44.9 \pm 3.8 b$ & $41.5 \pm 3.9 b$ & $27.8 \pm 3.6 \mathrm{c}$ \\
\hline No LED + 7 g CF per plant & $52.3 \pm 2.6 \mathrm{ab}$ & $50.7 \pm 6.7 \mathrm{ab}$ & $48.8 \pm 2.5 \mathrm{ab}$ & $45.2 \pm 4.1 \mathrm{~b}$ & $41.5 \pm 4.1 \mathrm{~b}$ & $29.1 \pm 3.9 b c$ \\
\hline No LED + 9 g CF per plant & $57.8 \pm 3.4 \mathrm{ab}$ & $51.6 \pm 3.9 \mathrm{ab}$ & $49.3 \pm 4.3 \mathrm{ab}$ & $45.3 \pm 4.0 \mathrm{~b}$ & $42.0 \pm 4.3 b$ & $31.0 \pm 3.6 b c$ \\
\hline LED $1+5$ g CF per plant & $53.3 \pm 3.5 \mathrm{ab}$ & $53.2 \pm 4.7 \mathrm{ab}$ & $49.7 \pm 2.3 \mathrm{ab}$ & $45.5 \pm 4.2 b$ & $42.0 \pm 3.9 b$ & $31.2 \pm 3.5 \mathrm{bc}$ \\
\hline LED1 + 7 g CF per plant & $53.7 \pm 2.6 \mathrm{ab}$ & $52.5 \pm 3.5 \mathrm{ab}$ & $49.6 \pm 4.3 \mathrm{ab}$ & $45.7 \pm 4.0 \mathrm{~b}$ & $42.2 \pm 4.1 b$ & $31.8 \pm 5.8 \mathrm{bc}$ \\
\hline LED $1+9$ g CF per plant & $55.0 \pm 3.7 \mathrm{ab}$ & $53.5 \pm 3.7 \mathrm{ab}$ & $51.6 \pm 6.3 \mathrm{ab}$ & $46.8 \pm 3.9 \mathrm{~b}$ & $42.3 \pm 4.2 b$ & $32.0 \pm 4.3 \mathrm{bc}$ \\
\hline LED2 + 5 g CF per plant & $55.1 \pm 3.2 \mathrm{ab}$ & $53.7 \pm 3.7 \mathrm{ab}$ & $51.6 \pm 3.6 \mathrm{ab}$ & $47.5 \pm 5.3 b$ & $42.9 \pm 4.0 \mathrm{~b}$ & $32.8 \pm 2.9 \mathrm{ab}$ \\
\hline LED2 + 7 g CF per plant & $58.4 \pm 2.7 \mathrm{ab}$ & $57.0 \pm 7.2 \mathrm{a}$ & $54.8 \pm 3.2 \mathrm{a}$ & $50.6 \pm 2.5 \mathrm{ab}$ & $46.6 \pm 3.9 \mathrm{ab}$ & $33.3 \pm 4.2 \mathrm{ab}$ \\
\hline LED2 + 9 g CF per plant & $59.3 \pm 4.4 \mathrm{a}$ & $57.8 \pm 6.3 \mathrm{a}$ & $55.7 \pm 3.3 \mathrm{a}$ & $51.0 \pm 2.3 \mathrm{a}$ & $47.4 \pm 4.4 \mathrm{a}$ & $37.6 \pm 3.7 \mathrm{a}$ \\
\hline F-value & 24.8 & 36.2 & 39.9 & 56.8 & 62.1 & 43.6 \\
\hline Significance & $*$ & $*$ & $*$ & $*$ & $*$ & $*$ \\
\hline $\mathrm{CV}(\%)$ & 5.9 & 6.0 & 7.0 & 10.1 & 11.0 & 5.4 \\
\hline
\end{tabular}

Note: See Table 1

\section{Fruit size, volume and mass}

Fruit size, mass and volume increased with LED supplementary lighting (Table 3). LED2 was more effective than LED1 in bringing this effect. With LED2 lighting, fruit size increased by about $3 \mathrm{~cm}$, fruit mass by about $1,400 \mathrm{~g}$ and fruit volume by about $1,300 \mathrm{ml}$ relative to the control. LED1 caused smaller but significant increases in fruit size, mass and volume compared to the control. Fruit size, mass and volume also increased with increasing NPK level but differences were significant only for fruit mass. It was highest in plants fertilized with $9 \mathrm{~g}$ and lowest with $5 \mathrm{~g}$. Interaction effect of LED lighting and NPK fertilization was significant only for fruit mass and volume due to deviation from the main effect of LED or NPK treatment. For fruit mass, the effects of $7 \mathrm{~g}$ and $9 \mathrm{~g}$ in the control (no LED) and $5 \mathrm{~g}$ and $7 \mathrm{~g}$ under LED1 and LED2 were not significant. For fruit volume, the effects of the three NPK treatments under each of the lighting treatment did not significantly differ.

Peel and flesh thickness differed significantly with LED lighting and with NPK fertilization (Table 3). The values were highest in LED2 and lowest in the control corresponding to their effect on fruit size. The effect of LED1 and LED2 was comparable for peel thickness, while for flesh thickness, LED1 effect was inferior compared to that of LED2. Significant interaction effect was obtained for both parameters as only $5 \mathrm{~g}$ fertilizer for peel thickness and $5 \mathrm{~g}$ and $7 \mathrm{~g}$ for flesh thickness in the control (no LED) significantly differed from the effect of LED2 regardless of NPK level. 
Fruit size and mass are the main determinants of economic yield of melon. The results showed that LED lighting, particularly LED2, remarkably increased fruit yield as compared with the control and the increased fruit size was accompanied by the increase in thickness of the peel and flesh. This effect can be attributed to improved vegetative growth plant height and chlorophyll content, which could have increased photosynthetic capacity and assimilates production affecting fruit development. LED2 was more effective than LED1 in improving growth and correspondingly in increasing fruit yield. The use of red-blue LED was also found to increase the yield of other crops due to increased rates of photosynthesis (Shimazaki et al. 2007; Dong et al. 2014; Sabzalian et al. 2014; Piovene et al. 2015; Choi et al. 2016) and the increase in fruit yield was due to the increased fruit size rather than increased number of fruit per plant as in the case of strawberry (Nadalini et al. 2017). On the other hand, the increased fruit yield in response to NPK fertilization was consistent with earlier results in melon (Damarany \& Farag 1994; El-Desuki et al. 2000; Shafeek et al. 2015) and other cucurbits - watermelon (Ojo et al. 2014), pumpkin (Oloyede \& Adebooye 2013). As regards the combined effect of NPK fertilization and LED lighting, we did not find direct evidence in the literature. Overall, the results of the present study demonstrated that LED2 combined with the highest NPK level (9 $\mathrm{g}$ NPK per plant) produced the biggest and heaviest fruit resulted from the most vigorous vegetative growth measured in terms of plant height and chlorophyll content. Without LED combined with the lowest NPK level, fruit yield and vegetative growth were the lowest among treatments.

Table 3. Fruit size, weight, volume, peel thickness and flesh thickness of melon in response to LED supplementary lighting and complete fertilizer (NPK 15-15-15) application

\begin{tabular}{|c|c|c|c|c|c|}
\hline Factor/Treatments & $\begin{array}{l}\text { Fruit size } \\
(\mathrm{cm})\end{array}$ & $\begin{array}{c}\text { Fruit weight } \\
(\mathrm{g})\end{array}$ & $\begin{array}{l}\text { Fruit volume } \\
\text { (ml) }\end{array}$ & $\begin{array}{l}\text { Peel thickness } \\
(\mathrm{cm})\end{array}$ & $\begin{array}{c}\text { Flesh thickness } \\
(\mathrm{cm})\end{array}$ \\
\hline \multicolumn{6}{|c|}{ Main factor-LED } \\
\hline No LED & $16.6 \pm 2.1 \mathrm{~b}$ & $2081.1 \pm 56.3 \mathrm{c}$ & $2050.6 \pm 120.1 \mathrm{c}$ & $0.71 \pm 0.01 \mathrm{~b}$ & $2.60 \pm 0.02 \mathrm{c}$ \\
\hline LED1 & $18.0 \pm 3.1 \mathrm{ab}$ & $2560.0 \pm 79.9 b$ & $2537.0 \pm 98.7 b$ & $0.78 \pm 0.02 \mathrm{a}$ & $2.97 \pm 0.02 b$ \\
\hline LED2 & $19.3 \pm 1.7 \mathrm{a}$ & $3447.4 \pm 128.1 \mathrm{a}$ & $3340.1 \pm 132.2 \mathrm{a}$ & $0.84 \pm 0.02 \mathrm{a}$ & $3.40 \pm 0.03 \mathrm{a}$ \\
\hline F-value & 43.2 & 27.6 & 45.3 & 36.5 & 45.8 \\
\hline Significance & $*$ & $*$ & $*$ & $*$ & $*$ \\
\hline \multicolumn{6}{|c|}{ Sub-factor-Complete fertilizer (CF) } \\
\hline $5 \mathrm{~g} \mathrm{CF}$ per plant & $17.5 \pm 3.8$ & $2386.7 \pm 126.0 \mathrm{c}$ & $2374.4 \pm 123.4$ & $0.73 \pm 0.01 b$ & $2.67 \pm 0.05 b$ \\
\hline $7 \mathrm{~g} \mathrm{CF}$ per plant & $18.0 \pm 4.0$ & $2743.3 \pm 150.2 b$ & $2710.2 \pm 134.5$ & $0.79 \pm 0.08 \mathrm{a}$ & $2.83 \pm 0.07 \mathrm{~b}$ \\
\hline $9 \mathrm{~g} \mathrm{CF}$ per plant & $18.3 \pm 4.0$ & $2958.6 \pm 178.2 \mathrm{a}$ & $2843.0 \pm 162.5$ & $0.81 \pm 0.06 \mathrm{a}$ & $3.14 \pm 0.09 \mathrm{a}$ \\
\hline F-value & 65.1 & 45.4 & 24.7 & 42.4 & 27.5 \\
\hline Significance & ns & $*$ & $\mathrm{~ns}$ & $*$ & $*$ \\
\hline \multicolumn{6}{|c|}{ Interaction effect $(\mathrm{LED} \times \mathrm{CF})$} \\
\hline No LED + 5 g CF per plant & $16.0 \pm 2.3$ & $1756.7 \pm 158.2 \mathrm{f}$ & $1794.0 \pm 132.5 \mathrm{e}$ & $0.62 \pm 0.05 b$ & $2.40 \pm 0.23 \mathrm{c}$ \\
\hline No LED + 7 g CF per plant & $16.6 \pm 3.1$ & $2230.0 \pm 141.2 \mathrm{e}$ & $2157.3 \pm 133.2 \mathrm{de}$ & $0.74 \pm 0.07 \mathrm{ab}$ & $2.62 \pm 0.17 \mathrm{bc}$ \\
\hline No LED + 9 g CF per plant & $17.2 \pm 2.9$ & $2256.7 \pm 132.3 \mathrm{e}$ & $2200.3 \pm 137.9 \mathrm{de}$ & $0.77 \pm 0.10 \mathrm{ab}$ & $2.70 \pm 0.24 \mathrm{abc}$ \\
\hline LED1 +5 g CF per plant & $17.9 \pm 3.1$ & $2316.7 \pm 134.2 \mathrm{e}$ & $2355.0 \pm 177.2 \mathrm{cde}$ & $0.77 \pm 0.12 \mathrm{ab}$ & $2.71 \pm 0.22 \mathrm{abc}$ \\
\hline LED1 +7 g CF per plant & $18.0 \pm 2.9$ & $2556.0 \pm 132.4 \mathrm{de}$ & $2466.7 \pm 132.6 \mathrm{bcd}$ & $0.79 \pm 0.12 \mathrm{ab}$ & $2.88 \pm 0.14 \mathrm{abc}$ \\
\hline LED1 +9 g CF per plant & $18.0 \pm 2.8$ & $2806.7 \pm 142.3 \mathrm{~cd}$ & $2789.3 \pm 168.9 \mathrm{bc}$ & $0.80 \pm 0.12 \mathrm{ab}$ & $3.30 \pm 0.27 \mathrm{ab}$ \\
\hline LED2 +5 g CF per plant & $18.6 \pm 2.7$ & $3086.7 \pm 132.5 b c$ & $2974.3 \pm 176.0 \mathrm{ab}$ & $0.81 \pm 0.16 \mathrm{a}$ & $3.37 \pm 0.21 \mathrm{a}$ \\
\hline LED2 + 7 g CF per plant & $19.4 \pm 2.8$ & $3443.3 \pm 186.2 b$ & $3506.7 \pm 198.3 \mathrm{a}$ & $0.84 \pm 0.16 \mathrm{a}$ & $3.40 \pm 0.19 \mathrm{a}$ \\
\hline LED2 + 9 g CF per plant & $19.8 \pm 3.2$ & $3812.3 \pm 144.2 \mathrm{a}$ & $3539.3 \pm 182.9 \mathrm{a}$ & $0.88 \pm 0.19 \mathrm{a}$ & $3.41 \pm 0.23 \mathrm{a}$ \\
\hline F-value & 45.9 & 23.6 & 29.4 & 56.3 & 45.4 \\
\hline Significance & $\mathrm{ns}$ & $*$ & $*$ & $*$ & $*$ \\
\hline $\mathrm{CV}(\%)$ & 7.8 & 4.6 & 7.6 & 7.9 & 8.6 \\
\hline
\end{tabular}

Note: See Table 1 
Table 4. Fruit peel color coordinates CIE L*, $\mathrm{a}^{*}$ and $\mathrm{b}^{*}$ values of melon in response to LED supplementary lighting and complete fertilizer (NPK 15-15-15) application

\begin{tabular}{|c|c|c|c|}
\hline Factor/Treatments & $\mathrm{L}^{*}$ & $a^{*}$ & $b^{*}$ \\
\hline \multicolumn{4}{|c|}{ Main factor-LED } \\
\hline No LED & $64.3 \pm 3.3 b$ & $13.2 \pm 1.3 \mathrm{a}$ & $27.7 \pm 5.2$ \\
\hline LED1 & $64.8 \pm 2.1 b$ & $14.0 \pm 2.5 \mathrm{a}$ & $28.2 \pm 3.5$ \\
\hline LED2 & $67.7 \pm 1.4 \mathrm{a}$ & $11.8 \pm 1.1 \mathrm{~b}$ & $27.3 \pm 3.5$ \\
\hline F-value & 56.7 & 32.5 & 22.9 \\
\hline Significance & $*$ & $*$ & ns \\
\hline \multicolumn{4}{|c|}{ Sub-factor-Complete fertilizer (CF) } \\
\hline $5 \mathrm{~g} \mathrm{CF}$ per plant & $65.3 \pm 5.6$ & $13.4 \pm 1.8 \mathrm{a}$ & $27.3 \pm 3.5$ \\
\hline $7 \mathrm{~g} \mathrm{CF}$ per plant & $65.8 \pm 4.3$ & $13.2 \pm 2.2 \mathrm{ab}$ & $28.3 \pm 4.6$ \\
\hline 9 g CF per plant & $65.8 \pm 4.2$ & $12.3 \pm 1.1 \mathrm{~b}$ & $27.6 \pm 3.8$ \\
\hline F-value & 45.9 & 56.1 & 37.3 \\
\hline Significance & ns & $*$ & ns \\
\hline \multicolumn{4}{|c|}{ Interaction effect $(\mathrm{LED} \times \mathrm{CF})$} \\
\hline No LED + 5 g CF per plant & $62.9 \pm 4.5$ & $14.4 \pm 1.3 \mathrm{ab}$ & $29.0 \pm 2.3 \mathrm{ab}$ \\
\hline No LED +7 g CF per plant & $64.8 \pm 6.2$ & $13.0 \pm 2.1 \mathrm{abc}$ & $27.4 \pm 1.8 \mathrm{ab}$ \\
\hline No LED + 9 g CF per plant & $65.1 \pm 3.5$ & $11.6 \pm 2.3 \mathrm{c}$ & $26.6 \pm 5.2 \mathrm{ab}$ \\
\hline LED $1+5$ g CF per plant & $66.1 \pm 3.9$ & $14.2 \pm 1.4 \mathrm{ab}$ & $26.9 \pm 1.6 \mathrm{ab}$ \\
\hline LED $1+7 \mathrm{~g} \mathrm{CF}$ per plant & $64.7 \pm 7.3$ & $14.6 \pm 2.4 \mathrm{a}$ & $29.6 \pm 2.7 \mathrm{a}$ \\
\hline LED $1+9$ g CF per plant & $63.8 \pm 4.3$ & $13.0 \pm 2.4 \mathrm{abc}$ & $28.1 \pm 4.3 \mathrm{ab}$ \\
\hline LED2 + 5 g CF per plant & $66.8 \pm 5.6$ & $11.5 \pm 4.7 \mathrm{c}$ & $25.9 \pm 3.2 b$ \\
\hline LED2 + 7 g CF per plant & $67.8 \pm 4.0$ & $11.8 \pm 2.8 \mathrm{c}$ & $27.9 \pm 3.3 \mathrm{ab}$ \\
\hline LED2 + 9 g CF per plant & $68.4 \pm 4.3$ & $12.2 \pm 1.2 \mathrm{bc}$ & $28.0 \pm 2.2 \mathrm{ab}$ \\
\hline F-value & 45.1 & 38.7 & 36.3 \\
\hline Significance & ns & $*$ & $*$ \\
\hline $\mathrm{CV}(\%)$ & 3.5 & 6.2 & 4.1 \\
\hline
\end{tabular}

Note: See Table 1

\section{Fruit color}

Fruit produced under LED2 lighting were lighter in color measured as higher lightness ( $\mathrm{L}^{*}$ ) values compared to that of fruit under LED1 and control treatments (Table 4). The effects of NPK fertilization and the interaction effect of LED and NPK treatments were not significant. The $\mathrm{a}^{*}$ values (green to red) were lower in fruit under LED2 comparing with LED1 and control. Fertilization with $9 \mathrm{~g}$ NPK significantly decreased $\mathrm{a}^{*}$ values, while $7 \mathrm{~g}$ had comparable effect as that of $5 \mathrm{~g}$. However, this effect was obtained only under no LED treatment, while under LED1 or LED2 conditions, the effect of the three NPK levels did not differ significantly. This accounted for the significant interaction effect of LED and NPK treatments. The $b^{*}$ values (blue to yellow) were not significantly affected by LED and NPK treatments but the interaction effect was significant and the application of $7 \mathrm{~g}$ under LED1 condition resulted in significantly higher $\mathrm{b}^{*}$ values than that of $5 \mathrm{~g}$ under LED2 condition.
The results indicate that LED2 exposure and high NPK fertilization caused a less saturated color of the fruit expressed with a lower $\mathrm{a}^{*}$ and higher $\mathrm{L}^{*}$ values compared to that of the other lighting and NPK treatments. Fruit color is the first quality attribute perceived by consumers at the point of purchase and a lighter color is desired for melons in Thailand. In tomato, colorimetric data on $\mathrm{a}^{*}$ and $\mathrm{b}^{*}$ coordinates that are correlated with lycopene content and red color showed that LED lighting reduced red color (lower $a^{*}$ and $b^{*}$ values) compared to the control (no LED) (Dzakovich et al. 2015). In strawberry, LED lighting particularly blue LED also reduced $\mathrm{a}^{*}$ and $b^{*}$ values (Nadalini et al. 2017). However, this is a negative quality factor as red color (high $\mathrm{a}^{*}$ values) is desired for the fruit. In contrast, LED lighting increased the anthocyanin content of strawberry, which is mainly responsible for the red fruit color (Kadomura-Ishikawa et al. 2013), while promoted red color development in tomato (Xu et al. 2012). 
The inconsistency of results could probably be due to the differences in light intensity and other growing conditions, which often was a problem when comparing the results of experiments conducted under different light parameters and cultural management systems (Lin et al. 2013).

\section{Fruit firmness}

LED1 and LED2 had comparable effect on flesh firmness, ranging from $51.3-57.5 \mathrm{~N}$, which was significantly higher than that of the control $-44.1 \mathrm{~N}$ (Table 5). Application of $9 \mathrm{~g}$ NPK resulted in firmer fruit $(55.4 \mathrm{~N})$ than that of $5 \mathrm{~g}(47.3 \mathrm{~N})$. At $7 \mathrm{~g} \mathrm{NPK}$, intermediate firmness values were obtained $(50.3 \mathrm{~N})$, which was not statistically different from that of the two other NPK levels. Interaction effect of LED and NPK treatments was significant as only LED2 combined with $9 \mathrm{~g}$ of fertilizer resulted in significantly higher firmness $(65.5 \mathrm{~N})$ than the control regardless of the NPK level (39.7-48.2 N).

Fruit firmness determines textural quality and susceptibility to physical damage due to handling hazards during the postharvest period. Firm flesh is a desired mouth feel quality in melons. The results showed that LED2 combined with $9 \mathrm{~g} \mathrm{NPK}$ was the most effective in producing high firmness fruit. It is speculated that the favorable effect of LED2 and high NPK levels on vegetative growth increased the rates of photosynthesis and assimilated the production and utilization in metabolic processes, including those responsible for cellular integrity and rigidity (e.g., pectin metabolism) that contribute to the overall fruit firmness. In an earlier study, LED lighting was found to have no effect on fruit firmness (Nadalini et al. 2017).

Table 5. Fruit firmness, total soluble solids (TSS), titratable acidity (TA) and juice pH of melon in response to LED supplementary lighting and complete fertilizer (NPK 15-15-15) application

\begin{tabular}{|c|c|c|c|c|}
\hline Factor/Treatments & Firmness $(\mathrm{N})$ & $\operatorname{TSS}\left({ }^{\circ}\right.$ Brix $)$ & TA $(\%)$ & Juice $\mathrm{pH}$ \\
\hline \multicolumn{5}{|c|}{ Main factor-LED } \\
\hline No LED & $44.1 \pm 3.2 b$ & $14.2 \pm 1.5 b$ & $0.6 \pm 0.01 \mathrm{a}$ & $6.6 \pm 1.3$ \\
\hline LED1 & $51.3 \pm 4.1 \mathrm{a}$ & $15.0 \pm 1.2 \mathrm{ab}$ & $0.4 \pm 0.02 b$ & $6.4 \pm 2.1$ \\
\hline LED2 & $57.5 \pm 3.2 \mathrm{a}$ & $15.8 \pm 2.1 \mathrm{a}$ & $0.2 \pm 0.02 \mathrm{c}$ & $6.1 \pm 2.0$ \\
\hline F-value & 23.2 & 28.3 & 29.5 & 46.6 \\
\hline Significance & $*$ & $*$ & $*$ & Ns \\
\hline \multicolumn{5}{|c|}{ Sub-factor-Complete fertilizer (CF) } \\
\hline $5 \mathrm{~g} \mathrm{CF}$ per plant & $47.3 \pm 2.5 b$ & $14.6 \pm 2.5$ & $0.3 \pm 0.01 b$ & $6.4 \pm 0.15$ \\
\hline $7 \mathrm{~g} \mathrm{CF}$ per plant & $50.3 \pm 3.8 \mathrm{ab}$ & $15.1 \pm 1.9$ & $0.5 \pm 0.02 \mathrm{a}$ & $6.3 \pm 0.08$ \\
\hline $9 \mathrm{~g} \mathrm{CF}$ per plant & $55.4 \pm 2.5 \mathrm{a}$ & $15.4 \pm 1.9$ & $0.5 \pm 0.02 \mathrm{a}$ & $6.3 \pm 0.11$ \\
\hline F-value & 28.2 & $24.5 \pm 2.11$ & 42.7 & 30.0 \\
\hline Significance & $*$ & ns & $*$ & ns \\
\hline \multicolumn{5}{|c|}{ Interaction effect $(\mathrm{LED} \times \mathrm{CF})$} \\
\hline No LED + 5 g CF per plant & $39.7 \pm 2.5 b$ & $13.5 \pm 3.5 b$ & $0.7 \pm 0.12 \mathrm{a}$ & $6.6 \pm 1.55$ \\
\hline No LED + 7 g CF per plant & $44.4 \pm 4.1 \mathrm{~b}$ & $14.5 \pm 2.6 \mathrm{ab}$ & $0.7 \pm 0.08 \mathrm{a}$ & $6.6 \pm 0.74$ \\
\hline No LED + 9 g CF per plant & $48.2 \pm 2.5 b$ & $14.5 \pm 3.5 \mathrm{ab}$ & $0.5 \pm 0.04 b$ & $6.5 \pm 1.25$ \\
\hline LED1 + 5 g CF per plant & $49.3 \pm 4.2 \mathrm{ab}$ & $14.8 \pm 4.2 \mathrm{ab}$ & $0.5 \pm 0.12 b$ & $6.4 \pm 1.51$ \\
\hline LED1 + 7 g CF per plant & $52.2 \pm 3.2 \mathrm{ab}$ & $15.1 \pm 1.3 \mathrm{ab}$ & $0.5 \pm 0.14 b$ & $6.4 \pm 1.34$ \\
\hline LED1 + 9 g CF per plant & $52.5 \pm 2.6 \mathrm{ab}$ & $15.2 \pm 2.7 \mathrm{ab}$ & $0.3 \pm 0.03 \mathrm{c}$ & $6.3 \pm 1.47$ \\
\hline LED2 + 5 g CF per plant & $52.9 \pm 3.1 \mathrm{ab}$ & $15.5 \pm 5.1 \mathrm{ab}$ & $0.3 \pm 0.05 \mathrm{c}$ & $6.3 \pm 1.41$ \\
\hline LED2 + 7 g CF per plant & $54.3 \pm 4.5 \mathrm{ab}$ & $15.7 \pm 3.9 \mathrm{ab}$ & $0.3 \pm 0.02 \mathrm{~cd}$ & $6.0 \pm 2.11$ \\
\hline LED2 + 9 g CF per plant & $65.5 \pm 6.2 \mathrm{a}$ & $16.4 \pm 3.0 \mathrm{a}$ & $0.1 \pm 0.01 \mathrm{~d}$ & $6.0 \pm 1.98$ \\
\hline F-value & 27.6 & 56.3 & 62.6 & 34.9 \\
\hline Significance & $*$ & $*$ & $*$ & ns \\
\hline $\mathrm{CV}(\%)$ & 11.1 & 6.6 & 9.8 & 3.8 \\
\hline
\end{tabular}

Note: See Table 1 


\section{Fruit chemical quality attributes}

LED lighting increased TSS content, with LED2 being more effective than LED1 (Table 5). TSS increased from $14.16^{\circ} \mathrm{B}$ in the control to $15.87^{\circ} \mathrm{B}$ in LED2. NPK application had no significant effect. Deviating from this main effect of LED and NPK treatments resulted in significant interaction effect. Only fruit from the control combined with $5 \mathrm{~g}$ fertilizer had markedly lower TSS content $\left(13.47^{\circ} \mathrm{B}\right)$ than fruit from LED2 combined with $9 \mathrm{~g}\left(16.4^{\circ} \mathrm{B}\right)$. Concomitant with the increase in TSS, TA content decreased in response to LED lighting (Table 5). TA decreased from $0.6 \%$ in the control to $0.2 \%$ in LED2; LED1 had intermediate effect. NPK fertilization increased TA content but the effect of $7 \mathrm{~g}$ and $9 \mathrm{~g}$ NPK was statistically comparable. Under each of the lighting treatment, application of the $9 \mathrm{~g}$ decreased TA content relative to lower NPK levels. This accounted for the significant interaction effect. Juice $\mathrm{pH}$ was statistically similar among all treatments and ranged from about 6.0-6.6 (Table 5).

Light quality has a pronounced effect on the accumulation of various metabolites in plants (Bian et al. 2015). Increased accumulation of plant metabolites (e.g., soluble sugars) was observed in the presence of red-blue LED. Natural daylight supplemented with red-blue LEDs increased the soluble sugars and organic acids in different crops (Samuolienė et al. 2012b; Lin et al. 2013; Samuolienè et al. 2013; Dong et al. 2014; Choi et al. 2015; Xie et al. 2016; Hasan et al. 2017). In melon, Cui et al. (2017) showed red:blue LED to be the most effective in increasing soluble sugar content. The results of the present study for TSS conform to this finding but the decrease in TA content was in contrast to the general effect of LED on organic acid accumulation, which is not always associated with $\mathrm{pH}$. Other investigators found no remarkable effect of LED lighting on fruit quality parameters such as TSS, $\mathrm{TA}$, and $\mathrm{pH}$; the authors concluded that LED supplementary lighting had neutral effect on fruit quality and can be used as alternative to other lighting supplements, such as HPS lamps (Dzakovich et al. 2015; Nadalini et al. 2017). On the other hand, NPK fertilization in melons is important to increase fruit yield and quality (El-Desuki et al. 2000). However, Shafeek et al. (2015) found that NPK application did not significantly affect total sugars and TSS content of melons. Similar results were obtained in the present study. The combined effect of NPK fertilization and LED lighting on melon fruit quality has not been so far reported. In this study, melon fruits produced under LED2 conditions combined with $9 \mathrm{~g}$ NPK 15-15-15 per plant were the sweetest (highest TSS) and had the lowest sourness or astringency (lowest TA content).

\section{CONCLUSION}

LED supplementary lighting and NPK 15-1515 application proved to be effective in promoting plant growth and increasing fruit yield and quality of melon in crops under plastic covers. LED2 combined with $9 \mathrm{~g}$ fertilizer per plant was the most effective in increasing plant height, chlorophyll content, and fruit size, mass and volume. It also caused thicker peel and flesh, lighter color, and firmer and sweeter flesh of fruit comparing with fruit obtained under other lighting and fertilizer treatments. To come up with a solid and cost-effective recommendation for commercial application in melon cultivar '\#120' production, confirmatory optimization trials can be conducted in future studies.

\section{REFERENCES}

Bian Z.H., Yang Q.C., Liu W.K. 2015. Effects of light quality on the accumulation of phytochemicals in vegetables produced in controlled environments: a review. Journal of Science of Food and Agriculture 95: 869-877. DOI: 10.1002/jsfa.6789.

Bourget C.M. 2008. An introduction to light-emitting diodes. HortScience 43(7): 1944-1946. DOI: 10.21273/hortsci.43.7.1944.

Choi H.G., Moon B.Y., Kang N.J. 2015. Effects of LED light on the production of strawberry during cultivation in a plastic greenhouse and in a growth chamber. Scientia Horticulturae 189: 22-31. DOI: 10.1016/j.scienta.2015.03.022.

Choi H.G., Moon B.Y., Kang N.J. 2016. Correlation between strawberry (Fragaria ananassa Duch.) productivity and photosynthesis-related parameters under various growth conditions. Frontiers in Plant Science 7; 1607; 13 p. DOI: 10.3389/fpls.2016.01607.

Cui X.H., Guo X.O., Sun T.Y., Qi H.Y. 2017. Effects of LED supplementary lighting on seedling growth and fruit 
quality of oriental melon. Plant Physiology Journal 53(4): 657-667. DOI: 10.13592/j.cnki.ppj.2016.0532. [in Chinese with English abstract]

Damarany A.M., Farag A.I. 1994. Effect of NPK levels and plant distance on yield and quality of cantaloupe fruits. Assiut Journal of Agricultural Sciences 25(4): 119-134.

Dong C., Fu Y., Liu G., Liu H. 2014. Growth, photosynthetic characteristics, antioxidant capacity and biomass yield and quality of wheat (Triticum aestivum L.) exposed to LED light sources with different spectra combinations. Journal of Agronomy and Crop Science 200: 219-230. DOI: 10.1111/jac.12059.

Dzakovich M.P., Gómez C., Mitchell C.A. 2015. Tomatoes grown with light-emitting diodes or high-pressure sodium supplemental lights have similar fruitquality attributes. HortScience 50(10): 1498-1502. DOI: $10.21273 /$ hortsci.50.10.1498.

El-Desuki M., Shafeek M.R., Sawan O.M. 2000. Effect of organic and mineral fertilization on growth, yield and quality of cantaloupe (Cucumis melo L.). Egyptian Journal of Applied Science 15(12): 585-603. [in Arabic with English abstract]

Ferrante A., Spinardi A., Maggiore T., Testoni A., Gallina P.M. 2008. Effect of nitrogen fertilisation levels on melon fruit quality at the harvest time and during storage. Journal of the Science of Food and Agriculture 88: 707-713. DOI: 10.1002/jsfa.3139.

Folta K.M., Carvalho S.D. 2015. Photoreceptors and control of horticultural plant traits. HortScience 50: 1274-1280. DOI: 10.21273/hortsci.50.9.1274.

Hao X., Zheng J.M., Little C., Khosla S. 2012. LED inter-lighting in year-round greenhouse mini-cucumber production. Acta Horticulturae 956: 335-340. DOI: 10.17660/actahortic.2012.956.38.

Hasan M.M., Bashir T., Ghosh R., Lee S.K., Bae H. 2017. An overview of LEDs' effects on the production of bioactive compounds and crop quality. Molecules 22: 1420; 12 p. DOI: 10.3390/molecules22091420.

Hernández R., Kubota C. 2012. Tomato seedling growth and morphological responses to supplemental LED lighting red:blue ratios under varied daily solar light integrals. Acta Horticulturae 956: 187-194. DOI: 10.17660/actahortic.2012.956.19.

Huché-Thélier L., Crespel L., Le Gourrierec J., Morel P., Sakr S., Leduc N. 2016. Light signalling and plant responses to blue and UV radiations - Perspectives for applications in horticulture. Environmental and Experimental Botany 121: 22-38. DOI: 10.1016/j.envexpbot.2015.06.009.
IPGRI 2003. Descriptors for melon (Cucumis melo L.). International Plant Genetic Resources Institute, Rome, Italy, $64 \mathrm{p}$.

Kadomura-Ishikawa Y., Miyawaki K., Noji S., Takahashi A. 2013. Phototropin 2 is involved in blue light-induced anthocyanin accumulation in Fragaria $\times$ ananassa fruits. Journal of Plant Research 126: 847857. DOI: 10.1007/s10265-013-0582-2.

Li Q., Kubota C. 2009. Effects of supplemental light quality on growth and phytochemicals of baby leaf lettuce. Environmental and Experimental Botany 67: 59-64. DOI: 10.1016/j.envexpbot.2009.06.011.

Li H., Tang C., Xu Z., Liu X., Han X. 2012. Effects of different light sources on the growth of non-heading Chinese cabbage (Brassica campestris L.). Journal of Agricultural Science 4: 262-273. DOI: $10.5539 /$ jas.v4n4p262.

Li H.M., Lu X.M., Gao Q.H. 2016. Effects of different light qualities on the growth, photosynthetic pigments and stomatal characteristics of okra (Abelmoschus esculentus) seedlings. Acta Prataculturae Sinica 25: 26-70. DOI: 10.11686/cyxb2016035.

Lin K.H., Huang M.Y., Huang W.D., Hsu M.H., Yang Z.W., Yang C.M. 2013. The effects of red, blue, and white light-emitting diodes on the growth, development, and edible quality of hydroponically grown lettuce (Lactuca sativa L. var. capitata). Scientia Horticulturae 150: 8691. DOI: 10.1016/j.scienta.2012.10.002.

Mengel K., Kirkby E.A. 1978. Principles of Plant Nutrition. International Potash Institute, Switzerland.

Mitchell C.A., Both A.J., Bourget C.M., Burr J.F., Kubota C., Lopez R.G. et al. 2012. LEDs: the future of greenhouse lighting! Chronica Horticulturae 52(1): 6-12.

Morrow R.C. 2008. LED lighting in horticulture. HortScience 43: 1947-1950. DOI: 10.21273/hortsci.43.7.1947.

Nadalini S., Zucchi P., Andreotti C. 2017. Effects of blue and red LED lights on soilless cultivated strawberry growth performances and fruit quality. European Journal of Horticultural Science 82(1): 12-20. DOI: $10.17660 /$ jhs.2017/82.1.2.

Ojo J.A., Olowoake A.A., Obembe A. 2014. Efficacy of organomineral fertilizer and un-amended compost on the growth and yield of watermelon (Citrullus lanatus Thumb) in Ilorin Southern Guinea Savanna zone of Nigeria. International Journal of Recycling of Organic Waste in Agriculture 3: 121-125. DOI: 10.1007/s40093-014-0073-z. 
Olle M., Viršilè A. 2013. The effects of light-emitting diode lighting on greenhouse plant growth and quality. Agricultural and Food Science 22: 223-234. DOI: 10.23986/afsci.7897.

Oloyede F.M., Adebooye O.C. 2013. Effect of planting date on the yield and proximate composition of pumpkin (Cucurbita pepo Linn.) fruit. British Journal of Applied Science and Technology 3(1): 174181. DOI: $10.9734 /$ bjast/2014/2201.

Ouzounis T., Rosenqvist E., Ottosen C.O. 2015. Spectral effects of artificial light on plant physiology and secondary metabolism: A review. HortScience 50: 1128-1135. DOI: 10.21273/hortsci.50.8.1128.

Piovene C., Orsini F., Bosi S., Sanoubar R., Bregola V., Dinelli G., Gianquinto G. 2015. Optimal red:blue ratio in led lighting for nutraceutical indoor horticulture. Scientia Horticulturae 193: 202-208. DOI: 10.1016/j.scienta.2015.07.015.

Sabzalian M.R., Heydarizadeh P., Zahedi M., Boroomand A., Agharokh M., Sahba M.R., Schoefs B. 2014. High performance of vegetables, flowers, and medicinal plants in a red-blue LED incubator for indoor plant production. Agronomy for Sustainable Development 34: 879-886. DOI: 10.1007/s13593-014-0209-6.

Samuolienė G., Brazaitytė A., Duchovskis P., Viršilè A., Jankauskienè J., Sirtautas R. et al. 2012a. Cultivation of vegetable transplants using solid-state lamps for the short-wavelength supplementary lighting in greenhouses. Acta Horticulturae 952: 885-892. DOI: 10.17660/actahortic.2012.952.112.

Samuolienė G., Sirtautas R., Brazaitytė A., Duchovskis P. 2012b. LED lighting and seasonality effects antioxidant properties of baby leaf lettuce. Food Chemistry 134: 1494-1499. DOI: 10.1016/j.foodchem.2012.03.061.
Samuolienė G., Brazaitytė A., Sirtautas R., Viršilè A., Sakalauskaitė J., Sakalauskienė S., Duchovskis P. 2013. LED illumination affects bioactive compounds in romaine baby leaf lettuce. Journal of Science of Food and Agriculture 93: 3286-3291. DOI: 10.1002/jsfa.6173.

Shafeek M.R., Shaheen A.M., Abd El-Samad E.H., Rizk F.A., Abd El-Al F.S. 2015. Response of growth, yield and fruit quality of cantaloupe plants (Cucumis melo L.) to organic and mineral fertilization. Middle East Journal of Applied Sciences 5(1): 76-82.

Shimazaki K.I., Doi M., Assmann S.M., Kinoshita T. 2007. Light regulation of stomatal movement. Annual Review of Plant Biology 58: 219-247. DOI: 10.1146/annurev.arplant.57.032905.105434.

Srimalee S. 2016. Rice farmer's switch to melon farming bears fruit. Retrieved from the Nation (Thailand).

Wang X., Sun Y. 2008. Report of graft experimentation of muskmelon. Ningbo Agricultural Technology 10(1): 10-11. [in Chinese with English abstract]

Xie B., Song S., Liu H., Sun G., Chen R. 2016. Effects of light quality on the quality formation of tomato fruits. Advances in Biological Sciences Research 3: 11-15. DOI: 10.2991/bep-16.2017.3.

Xu H.L., Xu Q., Li F., Feng Y., Qin F., Fang W. 2012. Applications of xerophytophysiology in plant production - LED blue light as a stimulus improved the tomato crop. Scientia Horticulturae 148: 190196. DOI: 10.1016/j.scienta.2012.06.044.

Yorio N.C., Goins G.D., Kagie H.R., Wheeler R.M., Sager J.C. 2001. Improving spinach, radish, and lettuce growth under red light-emitting diodes (LEDs) with blue light supplementation. HortScience 36: 380-383. DOI: 10.21273/hortsci.36.2.380. 